\title{
Amyotrophic lateral sclerosis: applications of stem cells - an update
}

This article was published in the following Dove Press journal:

Stem Cells and Cloning:Advances and Applications

22 October 2010

Number of times this article has been viewed

\section{Lidia Cova' \\ Vincenzo Silani \\ 'Department of Neurology and Laboratory of Neuroscience, IRCCS Istituto Auxologico Italiano, Milano, Italy; ${ }^{2}$ Department of Neurology and Laboratory of Neuroscience, "Dino Ferrari" Center, Università degli Studi di Milano, IRCCS Istituto Auxologico Italiano, Milano, Italy}

\begin{abstract}
Neurodegenerative diseases are a growing public health challenge, and amyotrophic lateral sclerosis (ALS) remains a fatal incurable disease. The advent of stem cell therapy has opened new horizons for both researchers and ALS patients, desperately looking for a treatment. ALS must be considered a systemic disease affecting many cell phenotypes besides motor neurons, even outside the central nervous system. Cell replacement therapy needs to address the specific neurobiological issues of ALS to safely and efficiently reach clinical settings. Moreover, the enormous potential of induced pluripotent cells directly derived from patients for modeling and understanding the pathological mechanisms, in correlation with the discoveries of new genes and animal models, provides new opportunities that need to be integrated with previously described transplantation strategies. Finally, a careful evaluation of preclinical data in conjunction with wary patient choice in clinical trials needs to be established in order to generate meaningful results.
\end{abstract}

Keywords: amyotrophic lateral sclerosis, regenerative medicine, stem cell therapy, clinical trials

\section{Introduction}

Amyotrophic lateral sclerosis (ALS) still remains, more than a century since first description, a fatal and untreatable disease. The use of pluripotent or multipotent cells for the restoration of damaged neuronal networks is one of the factors that holds promise from a translational medicine perspective and a relevant part of the strongest forces driving research in stem cell (SC) biology applied to neurodegenerative diseases. Novel specific neuropathological findings in ALS suggest a more generalized involvement outside the nervous system that needs to be fully evaluated before strategies for replacement or rescue of damaged neurons can be further developed.

\section{Amyotrophic lateral sclerosis and the frontotemporal involvement}

ALS is a fatal disease caused by the progressive loss of motor neurons (MNs) in both the brain and the spinal cord leading to paralysis of voluntary muscles and death within 2-5 years from clinical onset. ${ }^{1}$ Most cases of ALS are classified as sporadic ALS (sALS), albeit approximately 7\%-10\% are inherited in a dominant mode (familial ALS [fALS]). ${ }^{2}$ Although several hypotheses have been proposed to explain the specific MN involvement, leading to their progressive degeneration, the underlying mechanisms remain elusive. ${ }^{3}$

ALS has been considered to be the prototypical pyramidal motor system neurodegenerative disease for decades. In terms of neuropathology, degeneration of the upper and lower motor neuron with MN cytoplasmic inclusions immunoreactive for 
ubiquitin (U) and degeneration of the corticospinal tract were considered to be diagnostic for ALS. ${ }^{4}$ Recently, researchers have begun to recognize an important connection between frontotemporal dementia (FTD) and ALS or Lou Gehrig's disease (Figure 1A). FTD is a syndrome of progressive changes in behavior, language, and cognition due to loss of function of neurons in both the frontal and temporal lobes. Usually, FTD has relatively little effect on the parts of the nervous system that control movement, and so many FTD patients remain physically strong and relatively agile until late in the illness. However, in approximately $10 \%-15 \%$ of patients with FTD, the disease also involves the nerve cells controlling voluntary movement, the MNs. When this occurs, the syndrome is called FTD with motor neuron disease (FTDMND). TDP-43 (ubiquitinated TAR DNA-binding protein) is a multifunctional DNA/RNA-binding factor that has been implicated in the regulation of neuronal plasticity. ${ }^{5}$ The notion that pathological TDP-43 is involved in neurological diseases was proposed when it was discovered by Neumann et $\mathrm{al}^{6}$ since this protein has been identified as the major constituent of pathological inclusions in FTD with U (FTD-U, now known as FTD-TDP), FTD-MND, and ALS. Therefore, a common pathogenesis linked to TDP-43 abnormalities in these disorders has been suggested and further confirmed. ${ }^{5,7}$ This scheme reflects the considerable overlap of clinicopathological features between all neurodegenerative diseases: ${ }^{8}$ ALS, FTD-MND, and FTD-U may be situated at different points along a continuous and broad spectrum of a multisystemic degeneration ${ }^{9,10}$ (Figure 1A). Recent findings of mutations in the TARDBP gene, encoding for TDP-43, in cases of autosomal-dominant fALS and rare sALS patients further corroborate the significance of pathological TPD-43 as being mechanistically implicated in the disease process. ${ }^{11}$ Patients with both FTD-MND and TARDBP mutations have been reported. ${ }^{12}$ Recently, it has been demonstrated that elevated expression of TDP-43 in mouse forebrain causes neuropathological patterns similar to FTD-U, mimicking its specific behavior phenotype. ${ }^{13}$ Moreover, both TDP-43 and

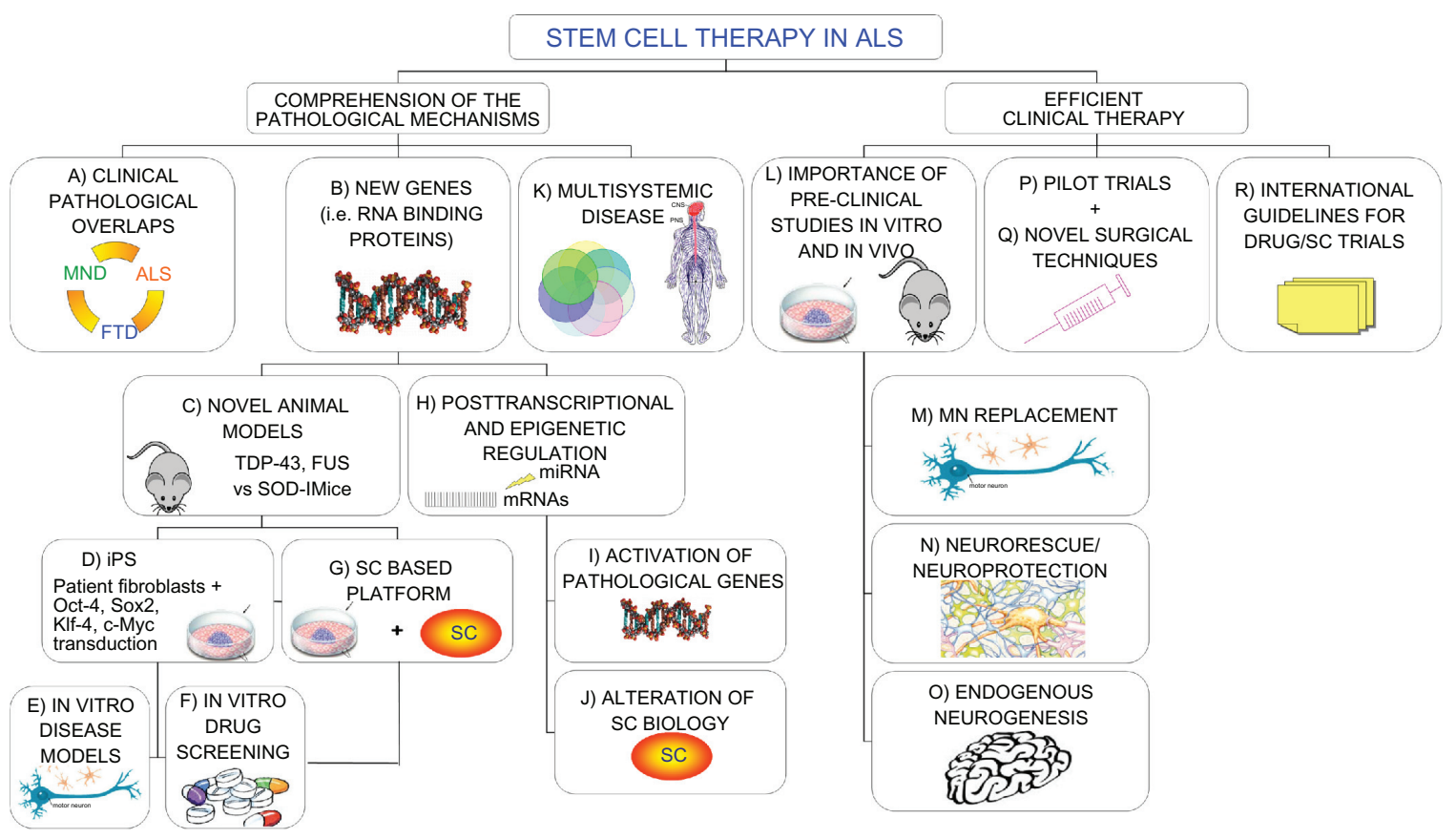

Figure I Novel "holistic" approach to ALS therapy. Clinical overlaps between ALS and other neurodegenerative diseases could unravel common molecular/pathological mechanisms (A). Moreover, new insights on causative genetic mutations (B) and the development of novel animal models (C) widen our knowledge of the possible therapeutic targets in the pathological pathways. In the meantime, recent iPS technology (D) provides patient-derived specimens as disease modeling and cell assays to dissect pathological mechanisms and specific cell contribution (E). The development of SC-based therapies is also directly exploitable for new drug screening ( $F$ and $\mathrm{G})$. The discovery of the importance of epigenetic regulation in the pathological processes is paralleled by a relevant role in SC biology. Any alteration in this complex network could alter SC dynamic cross talk to the diseased surroundings, thus precluding possible therapeutic effects $(\mathrm{H}-\mathrm{J})$. The complex nature requires a multifaceted strategy, able to efficiently contrast widespread degeneration in all tissue districts $(\mathrm{K})$, which should be carefully evaluated in accurate preclinical studies (L). Efficient therapeutic treatments are required both to replace MNs $(\mathrm{M})$ and provide an healthy environment for them $(\mathrm{N})$, capable also of enhancing endogenous repair (O). These laboratory studies will lead to successful clinical trials $(\mathrm{P})$, based on novel surgical techniques $(\mathrm{Q})$, able to slow the disease progression. Consensus international guidelines for drug/SC trials will guarantee the conscientious translation of basic SC research into appropriate treatment applications for patients aiming to create optimized efficient protocols able to slow down (neuro)degeneration (R).

Abbreviations: MND, motor neuron disease; ALS, amyotrophic lateral sclerosis; FTD, frontotemporal dementia; TDP-43, TAR DNA-binding protein; FUS, fused in sarcoma protein; iPS, induced pluripotent stem cells; Oct-4/Sox2/KIf-4/c-Myc, 4 transcription factors essential for iPS generation; SC, stem cell; miRNA, micro-RNA; MN, motor neuron. 
$\mathrm{Cu} / \mathrm{Zn}$ superoxide dismutase-1 (SOD-1) proteins modulate sequestration of neurofilament mRNAs in the aggregates characteristic in ALS MN degeneration. ${ }^{14}$

Mutations in a gene encoding another DNA/RNA-binding protein with striking structural and functional similarities to TDP-43 named FUS (fused in sarcoma) or TLS (translocation in liposarcoma) have been recently reported to trigger degeneration of $\mathrm{MNs}^{15-17}$ and be responsible for FTD. ${ }^{18}$ Although this gene was initially identified as a component of a fusion pro-oncogene resulting from a chromosomal translocation seen in liposarcomas, it belongs similarly to a subfamily of RNA-binding proteins, involved in $\mathrm{MN}$ (patho) physiological biology/metabolism (Figure 1B). Interestingly, FUS/TLS protein interacts with RNA, single-stranded DNA, and double-stranded DNA, and is involved in unique functions in the mRNA processing and transport, transcriptional regulation, and maintenance of genomic stability. ${ }^{19}$ It has been also reported the selective presence of FUS+ inclusions in an elderly patient apparently not mutated in the gene but affected by MND. ${ }^{20}$

The emerging scenario of multiple regional involvements due to the TDP-43/FUS neuropathological inclusions in the central nervous system (CNS) of ALS patients entails a significant impact on the therapeutic strategies applicable to them and, particularly, on the SC approach, since RNA-binding proteins appear as key regulators of signaling networks responsible for neuronal development and homeostasis, ${ }^{21}$ as well as neural SC biology. ${ }^{22}$ Therefore, healthy transplanted cells cross talk with the surroundings may also be compromised by the abnormal cellular RNA metabolism, able to trigger $\mathrm{MN}$ degeneration, thus impeding any therapeutic outcomes. FUS and TDP-43 harbor also a "prion domain" very similar to the specific one present in several yeast prion proteins prone to pathological misfolding transmissible within or between healthy cells or species. In this case, no SC strategy could maintain positive therapeutic outcomes in the long term, without a supportive treatment able to prevent the spread of the disease. ${ }^{23}$ Moreover, mere cell substitution appears insufficient to contrast all the alterations in the interrelated complex pathways activated by ALS, as described in the following paragraphs.

\section{Stem cells and new pharmacotherapeutic strategies: approaching novel genes, disease modeling, and drug candidates}

Additional interesting hints derive from the discovery of the novel pathological genes TARDBP $P^{6,24}$ and $F U S / T L S^{15}$ since they also have led to the derivation of new animal models, alternatives to the classic transgenic (tg) SOD-1, for deciphering the mechanisms responsible for the motor system neurodegeneration with large implications for SC therapies in the $\mathrm{CNS}^{25,26}$ (Figure 1C). In particular, it appears that TDP-43 plays a pivotal role in many forms of MND, and this protein, being implicated in some forms of dementia, exerts a contributory role in a wider number of neurodegenerative diseases. ${ }^{27}$ Moreover, a careful examination of the pathological SCs in these new animal models, as well as of the surrounding niche, could reveal abnormalities that may influence reparative mechanisms, as already suggested in tgSOD-1 NPs, ${ }^{28}$ wobbler mice, ${ }^{29}$ and in the bone marrow of sporadic ALS patients. ${ }^{30}$

Furthermore, remarkable pieces of information are expected from the recent generation of iPS cells (induced pluripotent SCs, obtained by transducing cells with 4 transcription factors: Oct-4, Sox2, K1f-4, and c-Myc; Figure 1D), deriving from somatic tissues of an elderly ALS patient, which could be successfully differentiated toward well-characterized MNs. ${ }^{31}$ iPS cells possess the same advantages as traditional SCs due to their ability to produce differentiated affected cells, such as neurons. ${ }^{32}$ However, the use of oncogenes and retrovirus in the current iPS cell establishment protocol raises safety concerns since their progeny show high teratoma-forming propensities that actually restricts their potential use in cell therapy. ${ }^{33}$ Nevertheless, neurodegenerative disease-specific iPS may be used for assays with cell specimens uncollectible from live patients (such as MNs, glial cells, and so on) to dissect their distinct peculiar influence on pathological events (Figure 1E) and to define new drug targets ${ }^{34}$ (Figure 1F). Although reprogramming adult patient cells would be particularly interesting for both fALS and sALS, so far no ALS iPS-derived MNs appear to be affected by the disease. Conversely, both iPS cells from spinal muscular atrophy ${ }^{35}$ (SMA) and familiar dysautonomia, ${ }^{36}$ characterized by childhood onset, recapitulate all the pathological selective deficits. Therefore, it appears that the complex interactions between genetic and environmental features combined to senescence processes, ${ }^{32}$ which are completely lacking during iPS-derived MN differentiation, may play a key role in ALS late-onset degeneration. Additional long-term studies would be necessary to recreate the correct pathophysiological conditions before validation of this model for drug screening or as a disease model for ALS.

A precise dissection of the synergistic effects of SC implantation on the ALS surroundings is limited by the 
absence of a primate model and by the still developing unique SC identification upon grafting. ${ }^{37}$ Additional studies to clarify the complex stem/niche interactions could be derived from in vitro cocultures as demonstrated by the pioneering experiments of both Di Giorgio and Nagai. Human embryonic SC (ES) - derived MNs selectively die whenever cultivated in the presence of tgSOD-1 MNs or glial cells through a Bax-dependent mechanism triggered by toxic soluble factors. ${ }^{38-40}$ These studies may conduct to the development of standardized SC-based platforms to study cell-cell interactions and to identify novel pharmacotherapeutic targets (Figure 1G).

Innovative perspectives are derived also by the novel findings on the importance of posttranscriptional and epigenetic regulation in neurodevelopment, as well as in neurodegenerative diseases. ${ }^{41}$ Recent evidence suggests that altered RNA metabolism may play a role in ALS pathogenesis ${ }^{16,19,42}$ (Figure 1H). Micro-RNAs (miRNAs) are small RNA molecules highly conserved and able to regulate the expression of genes by binding to the 3'-untranslated regions of target mRNAs. miRNAs have emerged as critical regulators of gene expression, and they have been implicated in the control of virtually all the biological processes, including the biology of SCs..$^{43}$ Recently, it has been described how the deficit of a specific miRNA expressed in skeletal muscle (miR-206) of tgSOD-1 mice led to compromised reinnervation of neuromuscular junction with an accelerated disease progression due to an increase of denervated muscle fibers. ${ }^{44}$ Moreover, recently a widespread modification in the total miRNA compartment after TDP-43 knockdown in culture cells has been reported, thus suggesting a direct link between the altered protein levels to specific candidate genes, crucial for TDP-43 pathogenic role in FTD and ALS. ${ }^{45}$ Concordantly, it has been recently suggested that $\mathrm{SC}$ biology is also strictly controlled by some differentially expressed miRNAs that act in concerted actions to regulate self-renewal, differentiation, and division. ${ }^{46,47}$ As a consequence, mere cell substitution by SC progeny alone could not recover a widespread compromised transcriptional regulation responsible for disease-related gene activation. Altogether, these novel findings support the idea that a combination of approaches, related to different pathological mechanisms, is needed for effective disease modeling and, consequently, cell therapies. Conversely, $\mathrm{SC}$ transplantation supporting the $\mathrm{MN}$ surroundings in conjunction with miRNAs or RNA interference using small inhibitory RNA (siRNA) to downregulate specific pathology-involved genes (such as TDP-43 and $G l u R 2)^{48,49}$ or RNAs may become, therefore, an innovative pharmacotherapeutic strategy to efficiently contrast both the MN degeneration and the environmental glial activation.

\section{ALS viewed as a systemic disease implies new therapeutic strategies}

The precise cause of ALS is still unknown, but several mutated genes have been found to predispose to ALS and recently other potential contributors to the complex pathological mechanism have been proposed ${ }^{50}$ Both sALS and fALS share similar clinical hallmarks, and some common genetic alterations, such as mutations in the SODI or TARDBP genes, are also reported in sALS, thus suggesting common pathological pathways. ${ }^{51}$ Moreover, the picture arising from different studies on ALS animal models and patients, leads to the idea that multiple cell types, even outside the motor system, result as pathophysiologically affected. Beside cognitive and personality changes, indicating frontotemporal involvement, abnormalities have been described in the fibril organization compartment of the skin, ${ }^{52-54}$ as well as in the spinal cord collagen content of ALS patients. ${ }^{55}$ Moreover, metalloproteinases (MMPs) involvements in different cellular districts have been reported as peculiar finding in ALS ${ }^{56,57}$ Widespread variations in several MMPs and their tissue inhibitors have been demonstrated in serum and cerebrospinal fluid of ALS patients, ${ }^{58-60}$ around atrophic myofibers, ${ }^{61}$ in mesenchymal $\mathrm{SCs},{ }^{30}$ and in postmortem brain/ spinal cord tissues in sALS cases. ${ }^{62}$ Alterations of MMPs were also retrieved in tgSOD-1 mice spinal cord, ${ }^{63}$ affecting both neuronal and glial cells. ${ }^{63}$ Moreover, early administration of MMP synthetic inhibitors extends survival in tg mice, ${ }^{64}$ while mutating tgSOD-1 mice knockout for a specific MMP (MMP9) show exacerbation of disease progression. ${ }^{65}$ Since MMPs are actively responsible for all cellular signaling cascades in a variety of physiological and pathological processes,${ }^{66}$ their widespread variations appear to involve all cell lineages in both the sporadic and familial forms of this neurodegenerative disorder. ALS patients are also hypermetabolic and present systemic alterations of lipidemia, ${ }^{67}$ while abnormal lipid clearance characterizes the pathological end stages of the tgSOD-1 mice. ${ }^{6}{ }^{2}$ Finally, it has been recently reported that mutant tgSOD-1 protein contributes to mitochondrial toxicity also in muscle tissue ${ }^{69}$ Interestingly, it has been recently suggested that the primary pathogenic event in tgSOD-1 mice involves muscle hypermetabolism which in turn causes neuromuscular junction destruction, followed by axonal degeneration, and finally MN loss. ${ }^{70}$

Altogether, this evidence supports the idea of a "multisystemic" disease, affecting multiple cell types, 
either neuronal or nonneuronal (Figure 1K). Notably, ALS involvement in SCs outside the motor system could represent a subject for consideration in autotransplantation of ALS patients, ${ }^{71-75}$ as discussed by our group in a recent article. ${ }^{30}$ Major metabolic pathways (such as MMP regulation, SC biology, mitochondrial toxicity, and metabolic rate), contemporaneously affected in different cellular districts, require an appropriate therapeutic strategy able to contrast all these pathological symptoms, instead of focusing mainly on MN degeneration. Therefore, outcomes of SC transplantation may be greatly improved by a global tactic directed toward MN substitution, recovery of the surroundings and rescue effect on suffering neurons (neurorescue effect), as well as action on different pathological mechanisms outside the CNS. Today, patients suffering from ALS may have a hope to improve their quality of life by slowing down or even healing their condition through SC technology combined with pharmacological approaches. This innovative concept deeply affects the traditional approach of SC therapy based on the need for MN replacement or protection to obtain clinical recovery in ALS patients: new cellular targets appear critical to slowing down MN degeneration, as well as more widespread symptoms, due to the broad organ involvement.

\section{MN replacement and the importance of surroundings for SC progeny in ALS}

The easiest clinical strategy in treating ALS should consist of the graft of SC-derived spinal MN precursors/neuroblasts to replace damaged or dead spinal neurons. Several interesting data have been already derived from in vitro and in vivo preclinical studies (Figure 1L). MNs have been generated from different lineages of SCs including mouse and human ES in vitro. ${ }^{76-80}$ These ES-derived MNs correctly innervate muscle fibers in vitro, ${ }^{81}$ as well as in motor-injured adult rats. ${ }^{82,83}$ Motor functions have been re-established by grafted embryonic cortical neurons ${ }^{84}$ whereas fetal neural progenitors (NPs) may well survive and proliferate both in vitro and in vivo after transplantation. ${ }^{85}$ Furthermore, they could be engineered to produce neutrophines, such as glial cell-derived neurotrophic factor, to protect host MNs during the pathological progression, ${ }^{86,87}$ while transfection of fully differentiated MNs would be difficult and less effective. However, both ES and fetal NP cells, as well as their progeny, possess advantages and limitations that ought to be considered. Actually, ES cells display unlimited growth in culture, an undifferentiated state and great differentiation potential associated with high risk to form teratomas.
Conversely, fetal NP cells exhibit long-term stability in culture and multiple differentiation potential in conjunction with absence of tumor formation, but both ethical and immunological constraints limit their use in humans. Moreover, ALS hostile inflammatory and oxidative environment could seriously challenge fully differentiated endogenous MNs, independent of their initial origin (ES or NPs). Therefore, the harsh surroundings may seriously hamper incorporation of grafted MNS into the host neural circuitry, target axonal growth, and reinnervate pathological muscle fibers. ${ }^{88}$

Surprisingly, both ES-derived MNs ${ }^{89,90}$ and NP-derived $\mathrm{MNS}^{69,91-93}$ transplanted in mice affected by SMA survived, integrated, and sprouted axonal terminals appropriately, thus ameliorating animal behavior, functional end points, and lifespan. These papers ${ }^{89,91}$ constitute the first important proof of principle that functional restoration of the motor circuit with SC-derived MNs is feasible and therapeutic through an overall neuroprotective effect associated with the decrease of proinflammatory molecules (Figure 1M). These milestone experiments also demonstrate how the complex axonal growth processes toward the skeletal muscle target could be driven and modulated by pharmacological treatment, even in adult mice. Nevertheless, many issues still need to be clarified before any clinical application: possible toxicity in human, surviving, migratory and differentiative potential of grafted cells in the degenerate environment, and their capacity to induce efficient synaptogenesis are still not fully analyzed and described..$^{94}$ Moreover, it is improbable that this approach could be soon translated in clinical trials since the restoration of the human motor circuit from MNs toward the appropriate muscle target will require considerable time (months or years) in a disease characterized by a mean survival of 36 months. Presently, it is unclear if transplanted SC-derived MNs may endure in the long term, once exposed to the harsh microenvironment of the spinal cord in ALS patients. ${ }^{88}$ Moreover, the progressive nature of ALS, characterized by time-increased dysfunctional astrocytes and overactivated microglia, may gradually damage grafted MNs, spreading pathological hallmarks from diseased to healthy cells, as demonstrated in transplanted parkinsonian patients. ${ }^{95}$ Actually, the importance of the surroundings during $\mathrm{MN}$ degeneration in ALS has been extensively proved, ${ }^{96-98}$ showing that disease onset can be delayed and survival increased in tgSOD-1 mice by providing genetically noncompromised supporting cells. ${ }^{99}$ Therefore, ALS appears to be even more convincingly a noncell autonomous process wherein different cell types (such as astrocytes and microglia) play a key role in the disease progression. ${ }^{100,101}$ On the other hand, SCs and 
their MN progeny may provide large quantities of affected MNs to define earlier pathological events relevant to disease initiation. ${ }^{102,103}$ As elegantly discussed in the recent review by Thonhoff et al, ${ }^{88}$ these specimens can also be used for studying glia-mediated toxin mechanisms and test potential therapies in ALS. ${ }^{38,104}$ In fact, ES-derived MNs expressing mutant tgSOD-1 recapitulate the main pathological hallmarks (reduced cell survival and shortened axonal processes) and may be exploited to elucidate ALS pathophysiology or to arrest degeneration using cell-based assays ${ }^{39,105}$ (Figure 1G). Moreover, riddance of immature myeloid precursor cells, abnormally proliferating during late pathological phases in tgSOD-1 mice, has enhanced how this process does not primarily affect $\mathrm{MN}$ degeneration, ${ }^{106}$ thus shifting research toward other potential targets such as inhibition of host immune or inflammatory response. ${ }^{107}$ As a matter of fact, bone marrow transplant reconstituted T-cell compartment, prolonged survival, and restored glial activation within tgSOD-1 mice lacking immune modulation. These results demonstrate that the absence of immune recruitment accelerates disease progression and death, while functional CD4+ T cells provide supportive neuroprotection by modulating the trophic/cytotoxic balance of glia. ${ }^{108} \mathrm{SC}$ choice, cell dose, and delivery route (as recently reviewed) ${ }^{107}$ are fundamental for a successful therapeutic strategy since subtle variations may cause divergent results. ${ }^{109,110}$ Nevertheless, several factors may influence enduring positive outcomes, other than structural integration in the mice motor circuitry ${ }^{111}$ or migration to patient injury sites. ${ }^{112}$ Due to its systemic and multifactorial nature, contrasting ALS entails multiple approaches able to contemporaneously act on different pathological mechanisms. As a matter of fact, effective growth release by engineered grafted SCs may be helpful to prevent MN loss, with an overall neurorescue effect able to slow down neuronal degeneration, thus avoiding pathological spreading to the surroundings. Nevertheless, additional strategies, such as SC differentiation toward glial cells, are required to preserve neuromuscular connections ${ }^{113,114}$ and to ameliorate pathological symptoms in ALS mice. ${ }^{115}$ Combining growth factor administration and SC therapy to increase healthy astroglial cell numbers also appears as a successful strategy to modulate disease progression by detoxification of the $\mathrm{MN}$ environment. ${ }^{114}$ Altogether, these new results point out the importance of multiple strategies able to counteract $\mathrm{MN}$ degeneration and positively influence the surrounding niche (Figure 1N).

Therefore, additional studies on the properties of SC progeny, in combination with pioneering cellular and molecular techniques, are required to provide a trophic environment for endogenous neural cells able also to contrast the reactive astrogliosis and microglial activation.

\section{Innovative SC therapies beyond replacement: neuroprotection by nonneural surrounding cells and activation of endogenous repair}

An interesting perspective comes from the observation that NP-derived neurons support host MNs in the tgSOD-1 rat model with an advanced degree of structural integration in the motor circuit, although in the absence of any replacement or new axonal innervations into target muscle. ${ }^{111}$ Moreover, recently it has been demonstrated that selective reduction of human SOD-1 levels in mice microglia or astrocytes, using a CRE-lox system, extends disease progression and host MN survival. ${ }^{98,99}$ Therefore, replacing nearby supporting cells appears a feasible strategy to preserve remaining $\mathrm{MN}$ functionality and activity. Transplantation of glial-restricted cell precursors by focal delivery into the ventral horn of the spinal cord extends both survival and disease duration, as well as attenuating MN loss. ${ }^{116}$ Interestingly, the observed neuroprotection appears partially due to normalization of the astrocyte glutamate transporter GLT1 levels, which is reduced in ALS patients and animal models. ${ }^{117,118}$ Concordantly, human adipose-derived SCs have the capability to increase their cytokine release when cocultured with tgSOD-1 astrocytes, which in turn show enhanced GLT1 expression and reduced caspase-3 activation, at least in vitro. ${ }^{119}$ Multiple neuroprotective effects including partial preservation of spinal cord GLT1 levels, modulation of growth factors, and microglial reduction have been recently reported after wild-type bone marrow-derived murine c-kit+ cells were systemically engrafted into tgSOD-1 mice. ${ }^{120}$ Microglia appears as another potential target for cell transplantation in ALS since wild-type bone marrow grafted into tgSOD-1 mice, both irradiated ${ }^{121}$ or lacking CNS microglia/peripheral immune cells, ${ }^{122}$ augments healthy microglial content with reduction of MN loss and increased animal survival. Replacement with normal allogenic hematopoietic SCs by intra-bone marrow-bone marrow transplantation in irradiated mice also improves the neural surroundings by delaying the disease progression, in contrast to the autologous tgSOD-1 graft. ${ }^{123}$ Unfortunately, hematopoietic SC transplantation in irradiated sporadic ALS patients has been demonstrated to be ineffective for improving clinical symptoms or survival, although implanted SCs correctly engraft injury sites, as demonstrated by autoptic samples. ${ }^{112}$ Conversely, grafts in frontal motor cortex of 
autologous multipotent hematopoietic CD-133 SCs, collected following mobilization, appear to be able to prolong ALS patient survival in a recent study, ${ }^{124}$ although no suggested mechanisms of action are provided. Similarly, two different open-label studies using bone marrow-derived hematopoietic progenitor $\mathrm{SCs}^{125}$ and autologous mesenchymal $\mathrm{SCs}^{72-74}$ report clinical benefits demonstrating that SC therapy is a safe, effective, and promising treatment for ALS patients still requiring additional evidence and standardization before being extensively applied in clinical practice. ${ }^{94}$

Although the mammalian CNS shows a very limited capacity to regenerate after injury, endogenous precursors/SCs may provide a potential source of new neurons in the adult brain and spinal cord. As a matter of fact, endogenous precursors can differentiate into highly complex long-projection corticospinal MNs and send new projections to spinal cord targets in the healthy, adult mammalian brain, following synchronous apoptotic degeneration. ${ }^{126}$ Alternative therapeutic strategies based on the modulation of adult neurogenesis have been already proposed and appeared promising for other neurodegenerative diseases, such as Parkinson disease (PD). ${ }^{94}$ Few data on this specific issue have been published in ALS models, but there is convincing evidence of widespread regenerative response, mainly toward glia, in the spinal cord of tgSOD-1 mice. ${ }^{127}$ Moreover, a temporal and regional plasticity of NPs in the dorsal horns of the spinal cord, as well as in motor cortex and lateral ventricle, in conjunction with their differentiation into neuron-like cells in response to $\mathrm{MN}$ loss, has been described during the disease onset or progression stages. ${ }^{128}$ These data suggest that, when stimulated by the neurodegenerative process, the adult spinal cord possesses, at least, limited ability for regeneration, which could be potentially exploited for therapeutic purposes (Figure 10). However, this endogenous response appears impossible in contrasting widespread degeneration, but may be strategically supported by allogenic SC grafts, as recently demonstrated in a PD model where reciprocal influences between implanted cells and endogenous NPs exert multiple neurorescue effects on several brain regions. ${ }^{129}$

Collectively, these data highlight how many potential protective strategies, alternative to $\mathrm{MN}$ replacement, may be explored for future applications to ALS therapy after careful testing in appropriate preclinical studies, clarifying the underlying mechanisms of action.

\section{Caveats and the importance of patient choice in clinical SC therapy}

The collected preclinical data demonstrate the feasibility of SC application to ALS animal models speeding the route towards clinical trials, but several hurdles limit a direct translation into new therapies, as clearly discussed by Lindvall and Kokaia. ${ }^{94}$ Retrieval of inconsistent behavioral improvements after SC grafting in animal models have not been paralleled by adequate comprehension of the underlying regulatory mechanisms exploitable for the development of standardized protocols applicable to patients. Altogether, the collected preclinical data show the feasibility of SC therapy for ALS, but more definitive answers are needed on the biological cascades activated by transplantation, such as the regulation of grafted SC behavior in terms of survival, proliferation and migration, as well as novel functional synaptogenesis, before widespread clinical trials can be contemplated. ${ }^{130}$

Multiple small pilot trials using a variety of different SC types have been published, but inconsistency on safety procedures, optimal cell dose/source, and delivery route reduce the interpretation of their potential efficiency ${ }^{107}$ (as detailed in Table 1). An impressive debate on expensive $\mathrm{SC}$ treatment offered worldwide has enlightened a complex reality where both meaningful interpretations and anecdotal reports are strictly linked. Nevertheless, since efficacious therapy is lacking, the severity of ALS might justify the potential risks of intervention in patients to demonstrate clinical feasibility of pioneering SC techniques. ${ }^{131}$

A clinical trial aimed to evaluate the safety of human SC implant in ALS patients is currently ongoing in the United States, which follows the preclinical validations of the surgical procedures. ${ }^{132}$ The SCs used in the study, prepared from cultured neural SCs, have previously been shown to extend the life of rats with $\mathrm{ALS}^{133}$ and reverse the paralysis in rats affected by ischemic spastic paraplegia. ${ }^{134}$ Direct neuronal differentiation of the grafted cells and release of growth factors to host MNs via graft-host connections have been suggested as the mechanisms responsible for the positive effects observed in both models. The phase 1 trial directed by Dr Glass at Emory University (Georgia, USA.) will enroll up to 12 ALS patients who will receive 5-10 SC injections in the lumbar area of the spinal cord. The patients will be examined at regular intervals after surgery, with final review of the data to come about 24 months later. Depending on the success of this initial trial, a follow-up phase 2 trial or a modified phase 1 trial is expected to implement the surgical and experimental procedures. The clinical trial is recruiting ALS patients (for additional data, refer Table 1).

Intravenous, intrathecal, and more often intraparenchymal administrations of hematopoietic SCs derived from peripheral blood or bone marrow have been tested in a small series of patients. ${ }^{73,112,124,125,135,136}$ Even if safety and lack of early side 
Table I Recent clinical trials with SCs in ALS patients (in chronological order)

\begin{tabular}{|c|c|c|c|c|c|}
\hline SC types & $\begin{array}{l}\text { Delivery route } \\
\text { (injection into) }\end{array}$ & $\begin{array}{l}\text { Patient } \\
\text { number }\end{array}$ & $\begin{array}{l}\text { Main patient } \\
\text { characteristics }\end{array}$ & $\begin{array}{l}\text { Outcome } \\
\text { (patient number) }\end{array}$ & Reference \\
\hline $\begin{array}{l}\text { Olfactory } \\
\text { ensheathing } \\
\text { cells }\end{array}$ & $\begin{array}{l}\text { Pathological regions of } \\
\text { the spinal cord and/or } \\
\text { bilateral corona radiata } \\
\text { of the brain }\end{array}$ & 327 & $\begin{array}{l}>\text { Onset spinal } \\
>\text { Age 20-84 } \\
>\text { Months from onset 4, 8-156 }\end{array}$ & $\begin{array}{l}\text { Safe and well tolerated } \\
(\text { short term }(4 \text { weeks)) } \\
\text { Few side effects }(16) \\
\text { Improvement rate of } \\
\text { neurological function (252) }\end{array}$ & 139 \\
\hline $\begin{array}{l}\text { Olfactory } \\
\text { ensheathing } \\
\text { cells }\end{array}$ & Frontal lobe & I & $\begin{array}{l}>\text { Onset spinal } \\
>\text { Age } 20-84 \\
>\text { Months from onset 4, 8-156 }\end{array}$ & $\begin{array}{l}\text { Faster disease rate } \\
\text { Disabling side-effects }\end{array}$ & 142 \\
\hline $\begin{array}{l}\text { Autologous } \\
\text { Bone marrow } \\
\text { mesenchymal } \\
\text { SCs }\end{array}$ & $\begin{array}{l}\text { Laminectomy + mielotomy } \\
\text { Central part of thoracic } \\
\text { spinal cord }\end{array}$ & 9 & $\begin{array}{l}>\text { Onset spinal } \\
>\text { Age 32-75 } \\
>\text { Months from diagnosis 8-60 }\end{array}$ & $\begin{array}{l}\text { Safe and well tolerated in } \\
\text { the long term ( } 4 \text { years } \\
\text { follow-up) }\end{array}$ & $7 I-75$ \\
\hline $\begin{array}{l}\text { Peripheral } \\
\text { blood SCs }\end{array}$ & $\begin{array}{l}\text { Mobilization with GCSF } \\
\text { treatment }\end{array}$ & 8 & $\begin{array}{l}>\text { Onset limb (7 patients) } \\
>\text { Age nr } \\
>\text { Months from onset 3-48 }\end{array}$ & $\begin{array}{l}\text { Safe and well tolerated } \\
\text { No significant changes in } \\
\text { disease progression }\end{array}$ & 135 \\
\hline $\begin{array}{l}\text { Mobilized } \\
\text { allogenic } \\
\text { hematopoietic } \\
\text { SCs }\end{array}$ & $\begin{array}{l}\text { Total body irradiation } \\
\text { Intravenous infusion } \\
\text { Immuno-suppression }\end{array}$ & 6 & $\begin{array}{l}>\text { Onset spinal or bulbar } \\
>\text { Age 35-59 } \\
>\text { Months from diagnosis 5-30 }\end{array}$ & $\begin{array}{l}\text { Tolerated with some } \\
\text { immunological problems ( } 3 \text { ) } \\
\text { No clinical benefits } \\
\text { Immune cells in spinal cord } \\
\text { ( } 3 \text { autopsies) }\end{array}$ & 112 \\
\hline $\begin{array}{l}\text { Fetal olfactory } \\
\text { ensheathing } \\
\text { cells }\end{array}$ & $\begin{array}{l}\text { Bilateral corona radiata } \\
\text { involving the pyramidal } \\
\text { tracts of the frontal } \\
\text { lobes }\end{array}$ & 15 & $\begin{array}{l}>\text { Onset } \mathrm{nr} \\
>\text { Age } \mathrm{nr} \\
>\text { Months from diagnosis/onset nr }\end{array}$ & $\begin{array}{l}\text { Safe and well tolerated } \\
\text { (short term ( } 4 \text { months) } \\
\text { No significant difference } \\
\text { in the rate of progression } \\
\text { (first } 2 \text { months) } \\
\text { Significant difference in } \\
\text { functional deterioration } \\
\text { (last } 2 \text { months) (7) }\end{array}$ & 140 \\
\hline $\begin{array}{l}\text { Autologous } \\
\text { Bone marrow } \\
\text { hematopoietic } \\
\text { progenitors }\end{array}$ & $\begin{array}{l}\text { Laminectomy } \\
\text { Anterior part of spinal } \\
\text { cord }(\mathrm{Cl}-\mathrm{C} 2)\end{array}$ & 13 & $\begin{array}{l}>\text { Onset nr } \\
>\text { Age 34-7I } \\
>\text { Months from diagnosis 8-60 }\end{array}$ & $\begin{array}{l}\text { Clinical benefits }(9) \\
\text { (I year follow-up) } \\
\text { No clinical benefits (I) } \\
\text { (I year follow-up) }\end{array}$ & 125 \\
\hline $\begin{array}{l}\text { Autologous } \\
\text { blood purified } \\
\text { CDI33+ cells }\end{array}$ & $\begin{array}{l}\text { Bilateral implantation in } \\
\text { frontal motor cortex } \\
\text { with stereotaxy or } \\
\text { neuronavigation guidance }\end{array}$ & 10 & $\begin{array}{l}>\text { Onset spinal } \\
>\text { Age } 38-62 \\
>\text { Months from diagnosis 18-42 }\end{array}$ & $\begin{array}{l}\text { Safe and well tolerated } \\
\text { (I year follow-up) } \\
\text { Significant changes in disease } \\
\text { progression vs control group }\end{array}$ & 124 \\
\hline $\begin{array}{l}\text { Fetal olfactory } \\
\text { ensheathing } \\
\text { cells }\end{array}$ & $\begin{array}{l}\text { Bilateral corona radiata } \\
\text { involving the pyramidal } \\
\text { tracts of the frontal } \\
\text { lobes }\end{array}$ & 457 & $\begin{array}{l}>\text { Onset nr } \\
>\text { Age } \mathrm{nr} \\
>\text { Months from diagnosis nr }\end{array}$ & $\begin{array}{l}\text { Improvement of the patients' } \\
\text { neurological functions and/ } \\
\text { or decrease the progressive } \\
\text { deterioration }\end{array}$ & 141 \\
\hline $\begin{array}{l}\text { Autologous } \\
\text { Bone marrow } \\
\text { SCs }\end{array}$ & $\begin{array}{l}\text { Laminectomy } \\
\text { Posterior part } \\
\text { of spinal cord }\end{array}$ & 11 & $\begin{array}{l}>\text { Onset medullar } \\
>\text { Age 33-6I } \\
>\text { Months from diagnosis nr }\end{array}$ & $\begin{array}{l}\text { Safe and well tolerated in the } \\
\text { short term (some months) } \\
\text { Transient hematoma } 7 \text { days } \\
\text { after surgery(MRI) } \\
\text { Grafted cells in spinal cord } \\
\text { ( } 2 \text { autopsies) }\end{array}$ & 143 \\
\hline $\begin{array}{l}\text { Autologous } \\
\text { Bone marrow } \\
\text { SCs }\end{array}$ & Spinal tap & $\mathrm{nr}$ & $\mathrm{nr}$ & Ongoing patient enrolment & $\begin{array}{l}\text { Press release: } \\
\text { http://www. } \\
\text { tcacellulartherapy. } \\
\text { com/pdf/forbes } \\
\text { als-0I I0.pdf }\end{array}$ \\
\hline Neural SCs & $\begin{array}{l}\text { Lumbar area of } \\
\text { spinal cord }\end{array}$ & 12 & $\begin{array}{l}\text { Phase I trial ongoing } \\
4 \text { patient surgeries done } \\
\text { ( } 3 \text { patients with unilateral } \\
\text { injections, I patient } \\
\text { bilateral injections into } \\
\text { the spinal cord) }\end{array}$ & $\begin{array}{l}\text { Estimated } 24 \text { months } \\
\text { follow-up } \\
\text { Ongoing patient enrolment } \\
\text { Tolerated (short time) }\end{array}$ & $\begin{array}{l}\text { http://www2. } \\
\text { med.umich.edu/ } \\
\text { prmc/media/ } \\
\text { newsroom/details. } \\
\text { cfm?ID=1306 }\end{array}$ \\
\hline
\end{tabular}

Abbreviation: $\mathrm{nr}$, not reported. 
effects have been claimed, the majority of these studies did not exhibit solid preclinical evidence as recommended before translation to clinical application. ${ }^{137,138}$ Clinical efficacy appears unproven and long-term safety needs to be demonstrated (Figure 1P). A large number of ALS patients has been recently reported after intracerebral transplantation with olfactory ensheathing cells, ${ }^{139-141}$ with disabling side effects reported for a patient who received this therapy in Beijing, China.${ }^{142}$ No sham operations have been documented, and the interpretation of the reported data is difficult because it is generated mostly outside the construct of a well-designed clinical study (see Table 1). Finally, novel surgical techniques for efficient SC delivery within the spinal cord have to be developed and tested to maximize safety and to support grafted cell integration in the host circuits, as recently suggested by several reports ${ }^{73,132,143,144}$ (Figure 1Q).

Guidelines for clinical trials using SC need to be specifically designed for ALS patients after selection of the most appropriate end points to reach clinical significance (Figure 1R): the historical data related to cell transplantation in PD become instrumental in achieving this goal. The neurological community has to reach a consensus on the design of clinical trials and proceed with a long follow-up to define the outcomes.

\section{Conclusion}

$\mathrm{SC}$ contribution in understanding the relevant pathways involved in ALS pathobiology becomes as essential as the SC application to cell therapy: their exploitation, in combination with advanced molecular techniques (ie, cell engineering, siRNA, and miRNA application), will guarantee optimized and innovative protocols for cell therapy, as well as new drug or pharmacological strategies able to influence the pathological progression of ALS. The emerging evidence of ALS as a system disease affecting, besides the CNS, also several peripheral organs in the affected patients will dictate new approaches to solve an old problem, namely the MN loss that still represents the more vulnerable side of a generalized process. Human iPS technology for generation of large numbers of MNs and other cells could help to further define generalized disease mechanism, offering powerful biological assays for drug screening. These combined efforts could broaden the chance of success, and thus, the journey that started in 1993 with the identification of the first underlying genetic defects in ALS could finally lead to successful therapy in ALS patients.

\section{Abbreviations}

ALS, amyotrophic lateral sclerosis; ES, embryonic stem cells; iPS inducible pluripotent stem cells; FTD, frontotemporal dementia; FTD-U, frontotemporal dementia with ubiquitin inclusions; $\mathrm{MN}$, motor neuron; $\mathrm{MND}$, motor neuron disease; NP, neural progenitor; SC, stem cell; SMA, spinal muscular atrophy; SOD-1, superoxide dismutase; U inclusion, Ubiquitin-positive inclusion.

\section{Acknowledgment}

This study was kindly supported financially by Francesco Caleffi and the Peviani family.

\section{Disclosure}

The authors have no conflicts of interest that are directly relevant to the content of this review.

\section{References}

1. Bruijn LI, Miller TM, Cleveland DW. Unraveling the mechanisms involved in motor neuron degeneration in ALS. Annu Rev Neurosci. 2004;27:723-749.

2. Kunst CB. Complex genetics of amyotrophic lateral sclerosis. Am J Hum Genet. 2004;75:933-947.

3. Pasinelli P, Brown RH. Molecular biology of amyotrophic lateral sclerosis: insights from genetics. Nat Rev Neurosci. 2006;7:710-723.

4. Hirano A. Neuropathology of ALS: an overview. Neurology. 1996;47: S63-S66.

5. Buratti E, Baralle FE. Multiple roles of TDP-43 in gene expression, splicing regulation, and human disease. Front Biosci. 2008;13: 867-878.

6. Neumann M, Sampathu DM, Kwong LK, et al. Ubiquitinated TDP-43 in frontotemporal lobar degeneration and amyotrophic lateral sclerosis. Science. 2006;314:130-133.

7. Arai T, Hasegawa M, Akiyama H, et al. TDP-43 is a component of ubiquitin-positive tau-negative inclusions in frontotemporal lobar degeneration and amyotrophic lateral sclerosis. Biochem Biophys Res Commun. 2006;351:602-611.

8. Armstrong RA, Lantos PL, Cairns NJ. Overlap between neurodegenerative disorders. Neuropathology. 2005;25:111-124.

9. Strong MJ. The syndromes of frontotemporal dysfunction in amyotrophic lateral sclerosis. Amyotroph Lateral Scler. 2008;9:323-338.

10. Strong MJ, Grace GM, Freedman M, et al. Consensus criteria for the diagnosis of frontotemporal cognitive and behavioural syndromes in amyotrophic lateral sclerosis. Amyotroph Lateral Scler. 2009;10: 131-146.

11. Corrado L, Ratti A, Gellera C, et al. High frequency of TARDBP gene mutations in Italian patients with amyotrophic lateral sclerosis. Hum Mutat. 2009;30:688-694.

12. Benajiba L, Le Ber I, Camuzat A, et al. TARDBP mutations in motoneuron disease with frontotemporal lobar degeneration. Ann Neurol. 2009; $65: 470-473$.

13. Tsai KJ, Yang CH, Fang YH, et al. Elevated expression of TDP-43 in the forebrain of mice is sufficient to cause neurological and pathological phenotypes mimicking FTLD-U. J Exp Med. 2010;207:1661-1673.

14. Volkening K, Leystra-Lantz C, Yang W, Jaffee H, Strong MJ. Tar DNA binding protein of $43 \mathrm{kDa}$ (TDP-43), 14-3-3 proteins and copper/zinc superoxide dismutase (SOD1) interact to modulate NFL mRNA stability. Implications for altered RNA processing in amyotrophic lateral sclerosis (ALS). Brain Res. 2009;1305:168-182.

15. Kwiatkowski TJ Jr, Bosco DA, Leclerc AL, et al. Mutations in the FUS/TLS gene on chromosome 16 cause familial amyotrophic lateral sclerosis. Science. 2009;323:1205-1208.

16. Lagier-Tourenne C, Cleveland DW. Rethinking ALS: the FUS about TDP-43. Cell. 2009;136:1001-1004. 
17. Vance C, Rogelj B, Hortobagyi T, et al. Mutations in FUS, an RNA processing protein, cause familial amyotrophic lateral sclerosis type 6 . Science. 2009;323:1208-1211.

18. Ticozzi N, Silani V, LeClerc AL, et al. Analysis of FUS gene mutation in familial amyotrophic lateral sclerosis within an Italian cohort. Neurology. 2009;73:1180-1185.

19. Yang S, Warraich ST, Nicholson GA, Blair IP. Fused in sarcoma/ translocated in liposarcoma: A multifunctional DNA/RNA binding protein. Int J Biochem Cell Biol. 2010;42:1408-1411.

20. Fujita Y, Fujita S, Takatama M, Ikeda M, Okamoto K. Numerous FUSpositive inclusions in an elderly woman with motor neuron disease. Neuropathology. 2010. doi:10.1111/j.1440-1789.2010.01146.x.

21. Bolognani F, Perrone-Bizzozero NI. RNA-protein interactions and control of mRNA stability in neurons. J Neurosci Res. 2008;86: 481-489.

22. Deschenes-Furry J, Perrone-Bizzozero N, Jasmin BJ. The RNA-binding protein $\mathrm{HuD}$ : a regulator of neuronal differentiation, maintenance and plasticity. Bioessays. 2006;28:822-833.

23. Cushman M, Johnson BS, King OD, Gitler AD, Shorter J. Prion-like disorders: blurring the divide between transmissibility and infectivity. J Cell Sci. 2010;123:1191-1201.

24. Ticozzi N, Leclerc AL, van Blitterswijk M, et al. Mutational analysis of TARDBP in neurodegenerative diseases. Neurobiol Aging. 2009. doi:10.1016/j.neurobiolaging. 2009. 11.018.

25. LiY, Ray P, Rao EJ, et al. A Drosophila model for TDP-43 proteinopathy. Proc Natl Acad Sci US A. 107:3169-3174.

26. Zhou H, Huang $\mathrm{C}$, Chen $\mathrm{H}$, et al. transgenic rat model of neurodegeneration caused by mutation in the TDP gene. PLoS Genet. 2010;6:e1000887.

27. Sleegers K, Cruts M, van Broeckhoven C. Molecular Pathways of Frontotemporal Lobar Degeneration. Annu Rev Neurosci. 2010;33:71-88.

28. Liu Z, Martin LJ. The adult neural stem and progenitor cell niche is altered in amyotrophic lateral sclerosis mouse brain. J Comp Neurol. 2006;497:468-488.

29. Diana V, Ottolina A, Botti F, et al. Neural precursor derived astrocytes of wobbler mice induce apoptotic death of motor neurons through reduced glutamate uptake. Exp Neurol. 2010. doi:10.1016/j. expneurol.2010.06.008.

30. Bossolasco P, Cova L, Calzarossa C, et al. Metalloproteinase alterations in the bone marrow of ALS patients. J Mol Med. 2010;88:553-564.

31. Dimos JT, Rodolfa KT, Niakan KK, et al. Induced pluripotent stem cells generated from patients with ALS can be differentiated into motor neurons. Science. 2008;321:1218-1221.

32. Kiskinis E, Eggan K. Progress toward the clinical application of patientspecific pluripotent stem cells. J Clin Invest. 2010;120:51-59.

33. Miura K, Okada Y, Aoi T, et al. Variation in the safety of induced pluripotent stem cell lines. Nat Biotechnol. 2009;27:743-745.

34. Inoue $H$. Neurodegenerative disease-specific induced pluripotent stem cell research. Exp Cell Res. 2010. doi:10.1016/j.yexcr.2010.04.022.

35. Ebert AD, Yu J, Rose FF Jr, et al. Induced pluripotent stem cells from a spinal muscular atrophy patient. Nature. 2009;457:277-280.

36. Lee G, Papapetrou EP, Kim H, et al. Modelling pathogenesis and treatment of familial dysautonomia using patient-specific iPSCs. Nature. 2009;461:402-406.

37. Villa C, Erratico S, Razini P, et al. Stem cell tracking by nanotechnologies. Int J Mol Sci. 2010;11:1070-1081.

38. Di Giorgio FP, Boulting GL, Bobrowicz S, Eggan KC. Human embryonic stem cell-derived motor neurons are sensitive to the toxic effect of glial cells carrying an ALS-causing mutation. Cell Stem Cell. 2008;3:637-648.

39. Di Giorgio FP, Carrasco MA, Siao MC, Maniatis T, Eggan K. Noncell autonomous effect of glia on motor neurons in an embryonic stem cell-based ALS model. Nat Neurosci. 2007;10:608-614.

40. Nagai M, Re DB, Nagata T, et al. Astrocytes expressing ALS-linked mutated SOD1 release factors selectively toxic to motor neurons. Nat Neurosci. 2007;10:615-622.

41. Weinberg MS, Wood MJ. Short non-coding RNA biology and neurodegenerative disorders: novel disease targets and therapeutics. Hum Mol Genet. 2009;18:R27-R39.
42. Strong MJ. The evidence for altered RNA metabolism in amyotrophic lateral sclerosis (ALS). J Neurol Sci. 2010;288:1-12.

43. Mallanna SK, Rizzino A. Emerging roles of microRNAs in the control of embryonic stem cells and the generation of induced pluripotent stem cells. Dev Biol. 2010;344:16-25.

44. Williams AH, Valdez G, Moresi V, et al. MicroRNA-206 delays ALS progression and promotes regeneration of neuromuscular synapses in mice. Science. 2009;326:1549-1554.

45. Buratti E, de Conti L, Stuani C, Romano M, Baralle M, Baralle F. Nuclear factor TDP-43 can affect selected microRNA levels. FEBS J. 2010;277:2268-2281.

46. Inui M, Martello G, Piccolo S. MicroRNA control of signal transduction. Nat Rev Mol Cell Biol. 2010;11:252-263.

47. Wang Y, Russell I, Chen C. MicroRNA and stem cell regulation. Curr Opin Mol Ther. 2009;11:292-298.

48. Kawahara Y, Ito K, Sun H, Aizawa H, Kanazawa I, Kwak S. Glutamate receptors: RNA editing and death of motor neurons. Nature. 2004;427:801.

49. Mackenzie IR, Bigio EH, Ince PG, et al. Pathological TDP-43 distinguishes sporadic amyotrophic lateral sclerosis from amyotrophic lateral sclerosis with SOD1 mutations. Ann Neurol. 2007;61: 427-434.

50. Kikuchi H, Almer G, Yamashita S, et al. Spinal cord endoplasmic reticulum stress associated with a microsomal accumulation of mutant superoxide dismutase-1 in an ALS model. Proc Natl Acad Sci U S A. 2006;103:6025-6030.

51. Gruzman A, Wood WL, Alpert E, et al. Common molecular signature in SOD1 for both sporadic and familial amyotrophic lateral sclerosis. Proc Natl Acad Sci U S A. 2007;104:12524-12529.

52. Ono S. The skin in amyotrophic lateral sclerosis. Amyotroph Lateral Scler Other Motor Neuron Disord. 2000;1:191-199.

53. Ono S, Imai T, Shimizu N, Nakayama M, Yamano T, Tsumura M. Serum markers of type I collagen synthesis and degradation in amyotrophic lateral sclerosis. Eur Neurol. 2000;44:49-56.

54. Provinciali L, Cangiotti A, Tulli D, Carboni V, Cinti S. Skin abnormalities and autonomic involvement in the early stage of amyotrophic lateral sclerosis. J Neurol Sci. 1994;126:54-61.

55. Ono S, Imai T, Munakata S, et al. Collagen abnormalities in the spinal cord from patients with amyotrophic lateral sclerosis. J Neurol Sci. 1998;160:140-147.

56. Fang L, Huber-Abel F, Teuchert M, et al. Linking neuron and skin: Matrix metalloproteinases in amyotrophic lateral sclerosis (ALS). J Neurol Sci. 2009;285:62-66.

57. Ludolph AC. Matrix metalloproteinases - a conceptional alternative for disease-modifying strategies in ALS/MND? Exp Neurol. 2006;201: 277-280.

58. Beuche W, Yushchenko M, Mader M, Maliszewska M, Felgenhauer K, Weber F. Matrix metalloproteinase-9 is elevated in serum of patients with amyotrophic lateral sclerosis. Neuroreport. 2000;11: 3419-3422.

59. Demestre M, Parkin-Smith G, Petzold A, Pullen AH. The pro and the active form of matrix metalloproteinase- 9 is increased in serum of patients with amyotrophic lateral sclerosis. J Neuroimmunol. 2005; 159:146-154.

60. Niebroj-Dobosz I, Janik P, Sokolowska B, Kwiecinski H. Matrix metalloproteinases and their tissue inhibitors in serum and cerebrospinal fluid of patients with amyotrophic lateral sclerosis. Eur J Neurol. 2010; 17:226-231

61. Schoser BG, Blottner D. Matrix metalloproteinases MMP-2, MMP-7 and MMP-9 in denervated human muscle. Neuroreport. 1999; 10:2795-2797.

62. Lim GP, Backstrom JR, Cullen MJ, Miller CA, Atkinson RD, Tokes ZA. Matrix metalloproteinases in the neocortex and spinal cord of amyotrophic lateral sclerosis patients. J Neurochem. 1996;67:251-259.

63. Kiaei M, Kipiani K, Calingasan NY, et al. Matrix metalloproteinase-9 regulates TNF-alpha and FasL expression in neuronal, glial cells and its absence extends life in a transgenic mouse model of amyotrophic lateral sclerosis. Exp Neurol. 2007;205:74-81. 
64. Lorenzl S, Narr S, Angele B, et al. The matrix metalloproteinases inhibitor Ro 26-2853 extends survival in transgenic ALS mice. Exp Neurol. 2006;200:166-171.

65. Dewil M, Schurmans C, Starckx S, Opdenakker G, van Den Bosch L, Robberecht W. Role of matrix metalloproteinase-9 in a mouse model for amyotrophic lateral sclerosis. Neuroreport. 2005;16:321-324.

66. Malemud CJ. Matrix metalloproteinases (MMPs) in health and disease: an overview. Front Biosci. 2006;11:1696-1701.

67. Dupuis L, Corcia P, Fergani A, et al. Dyslipidemia is a protective factor in amyotrophic lateral sclerosis. Neurology. 2008;70:1004-1009.

68. Fergani A, Oudart H, Gonzalez De Aguilar JL, et al. Increased peripheral lipid clearance in an animal model of amyotrophic lateral sclerosis. J Lipid Res. 2007;48:1571-1580.

69. Corti S, Donadoni C, Ronchi D, et al. Amyotrophic lateral sclerosis linked to a novel SOD1 mutation with muscle mitochondrial dysfunction. J Neurol Sci. 2009;276:170-174.

70. Dupuis L, Loeffler JP. Neuromuscular junction destruction during amyotrophic lateral sclerosis: insights from transgenic models. Curr Opin Pharmacol. 2009;9:341-346.

71. Mazzini L, Fagioli F, Boccaletti R. Stem-cell therapy in amyotrophic lateral sclerosis. Lancet. 2004;364:1936-1937.

72. Mazzini L, Fagioli F, Boccaletti R, et al. Stem cell therapy in amyotrophic lateral sclerosis: a methodological approach in humans. Amyotroph Lateral Scler Other Motor Neuron Disord. 2003;4: 158-161.

73. Mazzini L, Ferrero I, Luparello V, et al. Mesenchymal Stem Cell Transplantation In Amyotrophic Lateral Sclerosis: A Phase I Clinical Trial. Exp Neurol. 2009. doi:10.1016/j.expneurol.2009.08.007.

74. Mazzini L, Mareschi K, Ferrero I, et al. Autologous mesenchymal stem cells: clinical applications in amyotrophic lateral sclerosis. Neurol Res. 2006;28:523-526.

75. Mazzini L, Mareschi K, Ferrero I, et al. Stem cell treatment in Amyotrophic Lateral Sclerosis. J Neurol Sci. 2008;265:78-83.

76. Lee H, Shamy GA, Elkabetz Y, et al. Directed differentiation and transplantation of human embryonic stem cell-derived motoneurons. Stem Cells. 2007;25:1931-1939.

77. Li XJ, Du ZW, Zarnowska ED, et al. Specification of motoneurons from human embryonic stem cells. Nat Biotechnol. 2005;23:215-221.

78. Li XJ, Hu BY, Jones SA, et al. Directed differentiation of ventral spinal progenitors and motor neurons from human embryonic stem cells by small molecules. Stem Cells. 2008;26:886-893.

79. Singh Roy N, Nakano T, Xuing L, Kang J, Nedergaard M, Goldman SA. Enhancer-specified GFP-based FACS purification of human spinal motor neurons from embryonic stem cells. Exp Neurol. 2005;196: 224-234

80. Wichterle H, Lieberam I, Porter JA, Jessell TM. Directed differentiation of embryonic stem cells into motor neurons. Cell. 2002;110: 385-397.

81. Miles GB, Yohn DC, Wichterle H, Jessell TM, Rafuse VF, Brownstone RM. Functional properties of motoneurons derived from mouse embryonic stem cells. J Neurosci. 2004;24:7848-7858.

82. Deshpande DM, Kim YS, Martinez T, et al. Recovery from paralysis in adult rats using embryonic stem cells. Ann Neurol. 2006;60: $32-44$.

83. Harper JM, Krishnan C, Darman JS, et al. Axonal growth of embryonic stem cell-derived motoneurons in vitro and in motoneuron-injured adult rats. Proc Natl Acad Sci U S A. 2004;101:7123-7128.

84. Gaillard A, Prestoz L, Dumartin B, et al. Reestablishment of damaged adult motor pathways by grafted embryonic cortical neurons. Nat Neurosci. 2007;10:1294-1299.

85. Emgard M, Holmberg L, Samuelsson EB, et al. Human neural precursor cells continue to proliferate and exhibit low cell death after transplantation to the injured rat spinal cord. Brain Res. 2009;1278:15-26.

86. Capowski EE, Schneider BL, Ebert AD, et al. Lentiviral vector-mediated genetic modification of human neural progenitor cells for ex vivo gene therapy. J Neurosci Methods. 2007;163:338-349.

87. Klein SM, Behrstock S, McHugh J, et al. GDNF delivery using human neural progenitor cells in a rat model of ALS. Hum Gene Ther. 2005;16:509-521.
88. Thonhoff JR, Ojeda L, Wu P. Stem cell-derived motor neurons: applications and challenges in amyotrophic lateral sclerosis. Curr Stem Cell Res Ther. 2009;4:178-199.

89. Corti S, Nizzardo M, Nardini M, et al. Embryonic stem cell-derived neural stem cells improve spinal muscular atrophy phenotype in mice. Brain. 2010;133:465-481.

90. Yohn DC, Miles GB, Rafuse VF, Brownstone RM. Transplanted mouse embryonic stem-cell-derived motoneurons form functional motor units and reduce muscle atrophy. J Neurosci. 2008;28:12409-12418.

91. Corti S, Locatelli F, Papadimitriou D, et al. Neural stem cells LewisX+ CXCR4+ modify disease progression in an amyotrophic lateral sclerosis model. Brain. 2007;130:1289-1305.

92. Corti S, Nizzardo M, Nardini M, et al. Motoneuron transplantation rescues the phenotype of SMARD1 (spinal muscular atrophy with respiratory distress type 1). J Neurosci. 2009;29:11761-11771.

93. Corti S, Nizzardo M, Nardini M, et al. Neural stem cell transplantation can ameliorate the phenotype of a mouse model of spinal muscular atrophy. J Clin Invest. 2008;118:3316-3330.

94. Lindvall O, Kokaia Z. Stem cells in human neurodegenerative disorderstime for clinical translation? J Clin Invest. 2010;120:29-40.

95. Brundin P, Li JY, Holton JL, Lindvall O, Revesz T. Research in motion: the enigma of Parkinson's disease pathology spread. Nat Rev Neurosci. 2008;9:741-745.

96. Clement AM, Nguyen MD, Roberts EA, et al. Wild-type nonneuronal cells extend survival of SOD1 mutant motor neurons in ALS mice. Science. 2003;302:113-117.

97. Yamanaka K, Boillee S, Roberts EA, et al. Mutant SOD1 in cell types other than motor neurons and oligodendrocytes accelerates onset of disease in ALS mice. Proc Natl Acad Sci U S A. 2008;105: 7594-7599.

98. Yamanaka K, Chun SJ, Boillee S, et al. Astrocytes as determinants of disease progression in inherited amyotrophic lateral sclerosis. Nat Neurosci. 2008;11:251-253.

99. Boillee S, Yamanaka K, Lobsiger CS, et al. Onset and progression in inherited ALS determined by motor neurons and microglia. Science. 2006;312:1389-1392.

100. Hedlund E, Hefferan MP, Marsala M, Isacson O. Cell therapy and stem cells in animal models of motor neuron disorders. Eur J Neurosci. 2007;26:1721-1737.

101. Marchetto MC, Muotri AR, Mu Y, Smith AM, Cezar GG, Gage FH. Non-cell-autonomous effect of human SOD1 G37R astrocytes on motor neurons derived from human embryonic stem cells. Cell Stem Cell. 2008;3:649-657.

102. Ralph GS, Radcliffe PA, Day DM, et al. Silencing mutant SOD1 using RNAi protects against neurodegeneration and extends survival in an ALS model. Nat Med. 2005;11:429-433.

103. Raoul C, Abbas-Terki T, Bensadoun JC, et al. Lentiviral-mediated silencing of SOD1 through RNA interference retards disease onset and progression in a mouse model of ALS. Nat Med. 2005;11: 423-428.

104. Ebert AD, Svendsen CN. Human stem cells and drug screening: opportunities and challenges. Nat Rev Drug Discov. 2010;9:367-372.

105. Karumbayaram S, Kelly TK, Paucar AA, et al. Human embryonic stem cell-derived motor neurons expressing SOD1 mutants exhibit typical signs of motor neuron degeneration linked to ALS. Dis Model Mech. 2009;2:189-195.

106. Gowing G, Philips T, van Wijmeersch B, et al. Ablation of proliferating microglia does not affect motor neuron degeneration in amyotrophic lateral sclerosis caused by mutant superoxide dismutase. J Neurosci. 2008;28:10234-10244.

107. Mazzini L, Vercelli A, Ferrero I, et al. Stem cells in amyotrophic lateral sclerosis: state of the art. Expert Opin Biol Ther. 2009;9: 1245-1258.

108. Beers DR, Henkel JS, Zhao W, Wang J, Appel SH. CD4+ T cells support glial neuroprotection, slow disease progression, and modify glial morphology in an animal model of inherited ALS. Proc Natl Acad Sci US A. 2008;105:15558-15563. 
109. Habisch HJ, Janowski M, Binder D, et al. Intrathecal application of neuroectodermally converted stem cells into a mouse model of ALS: limited intraparenchymal migration and survival narrows therapeutic effects. J Neural Transm. 2007;114:1395-1406.

110. Kim H, Kim HY, Choi MR, et al. Dose-dependent efficacy of ALShuman mesenchymal stem cells transplantation into cisterna magna in SOD1-G93A ALS mice. Neurosci Lett. 468:190-194.

111. Xu L, Ryugo DK, Pongstaporn T, Johe K, Koliatsos VE. Human neural stem cell grafts in the spinal cord of SOD1 transgenic rats: differentiation and structural integration into the segmental motor circuitry. J Comp Neurol. 2009;514:297-309.

112. Appel SH, Engelhardt JI, Henkel JS, et al. Hematopoietic stem cell transplantation in patients with sporadic amyotrophic lateral sclerosis. Neurology. 2008;71:1326-1334.

113. Suzuki M, McHugh J, Tork C, et al. GDNF secreting human neural progenitor cells protect dying motor neurons, but not their projection to muscle, in a rat model of familial ALS. PLoS One. 2007;2:e689.

114. Suzuki M, Svendsen CN. Combining growth factor and stem cell therapy for amyotrophic lateral sclerosis. Trends Neurosci. 2008;31:192-198

115. Park S, Kim HT, Yun S, et al. Growth factor-expressing human neural progenitor cell grafts protect motor neurons but do not ameliorate motor performance and survival in ALS mice. Exp Mol Med. 2009;41:487-500.

116. Lepore AC, Rauck B, Dejea C, et al. Focal transplantation-based astrocyte replacement is neuroprotective in a model of motor neuron disease. Nat Neurosci. 2008;11:1294-1301.

117. Howland DS, Liu J, She Y, et al. Focal loss of the glutamate transporter EAAT2 in a transgenic rat model of SOD1 mutant-mediated amyotrophic lateral sclerosis (ALS). Proc Natl Acad Sci U S A. 2002;99: 1604-1609.

118. Maragakis NJ, Dykes-Hoberg M, Rothstein JD. Altered expression of the glutamate transporter EAAT2b in neurological disease. Ann Neurol. 2004;55:469-477.

119. Gu R, Hou X, Pang R, et al. Human adipose-derived stem cells enhance the glutamate uptake function of GLT1 in SOD1(G93A)-bearing astrocytes. Biochem Biophys Res Commun. 2010;393:481-486.

120. Corti S, Nizzardo M, Nardini M, et al. Systemic transplantation of c-kit+ cells exerts a therapeutic effect in a model of amyotrophic lateral sclerosis. Hum Mol Genet. 2010. doi:10.1093/hmg/ddq293.

121. Corti S, Locatelli F, Donadoni C, et al. Wild-type bone marrow cells ameliorate the phenotype of SOD1-G93A ALS mice and contribute to CNS, heart and skeletal muscle tissues. Brain. 2004;127: 2518-2532.

122. Beers DR, Henkel JS, Xiao Q, et al. Wild-type microglia extend survival in PU.1 knockout mice with familial amyotrophic lateral sclerosis. Proc Natl Acad Sci U S A. 2006;103:16021-16026.

123. Ohnishi S, Ito H, Suzuki Y, et al. Intra-bone marrow-bone marrow transplantation slows disease progression and prolongs survival in G93A mutant SOD1 transgenic mice, an animal model mouse for amyotrophic lateral sclerosis. Brain Res. 2009;1296:216-224.

124. Martinez HR, Gonzalez-Garza MT, Moreno-Cuevas JE, Caro E, Gutierrez-Jimenez E, Segura JJ. Stem-cell transplantation into the frontal motor cortex in amyotrophic lateral sclerosis patients. Cytotherapy. 2009;11:26-34.

125. Deda H, Inci MC, Kurekci AE, et al. Treatment of amyotrophic lateral sclerosis patients by autologous bone marrow-derived hematopoietic stem cell transplantation: a 1-year follow-up. Cytotherapy. 2009;11: 18-25.
126. Chen J, Magavi SS, Macklis JD. Neurogenesis of corticospinal motor neurons extending spinal projections in adult mice. Proc Natl Acad Sci US A. 2004;101:16357-16362.

127. Erie EA, Shim H, Smith AL, et al. Mice deficient in the ALS2 gene exhibit lymphopenia and abnormal hematopoietic function. JNeuroimmunol. 2007;182:226-231.

128. Chi L, Gan L, Luo C, Lien L, Liu R. Temporal response of neural progenitor cells to disease onset and progression in amyotrophic lateral sclerosis-like transgenic mice. Stem Cells Dev. 2007;16:579-588.

129. Cova L, Armentero MT, Zennaro E, et al. Multiple neurogenic and neurorescue effects of human mesenchymal stem cell after transplantation in an experimental model of Parkinson's disease. Brain Res. 2010;1311:12-27.

130. Garbuzova-Davis S, Sanberg PR. Feasibility of cell therapy for amyotrophic lateral sclerosis. Exp Neurol. 2009;216:3-6.

131. Gornall J. Stem cell renegades or pioneers? BMJ. 2010;340:c2041.

132. Riley J, Federici T, Park J, et al. Cervical spinal cord therapeutics delivery: preclinical safety validation of a stabilized microinjection platform. Neurosurgery. 2009;65:754-761; discussion 761-752.

133. Xu L, Yan J, Chen D, et al. Human neural stem cell grafts ameliorate motor neuron disease in SOD-1 transgenic rats. Transplantation. 2006;82:865-875.

134. Cizkova D, Kakinohana O, Kucharova K, et al. Functional recovery in rats with ischemic paraplegia after spinal grafting of human spinal stem cells. Neuroscience. 2007; 147:546-560.

135. Cashman N, Tan LY, Krieger C, et al. Pilot study of granulocyte colony stimulating factor (G-CSF)-mobilized peripheral blood stem cells in amyotrophic lateral sclerosis (ALS). Muscle Nerve. 2008;37:620-625.

136. Janson CG, Ramesh TM, During MJ, Leone P, Heywood J. Human intrathecal transplantation of peripheral blood stem cells in amyotrophic lateral sclerosis. J Hematother Stem Cell Res. 2001;10:913-915.

137. Badayan I, Cudkowicz ME. Is it too soon for mesenchymal stem cell trials in people with ALS? Amyotroph Lateral Scler. 2008;9:321-322.

138. Silani V, Cova L, Corbo M, Ciammola A, Polli E. Stem-cell therapy for amyotrophic lateral sclerosis. Lancet. 2004;364:200-202.

139. Chen L, Huang H, Zhang J, et al. Short-term outcome of olfactory ensheathing cells transplantation for treatment of amyotrophic lateral sclerosis. Zhongguo Xiu Fu Chong Jian Wai Ke Za Zhi. 2007;21: 961-966.

140. Huang H, Chen L, Xi H, et al. Fetal olfactory ensheathing cells transplantation in amyotrophic lateral sclerosis patients: a controlled pilot study. Clin Transplant. 2008;22:710-718.

141. Huang H, Chen L, Xi H, et al. Olfactory ensheathing cells transplantation for central nervous system diseases in 1,255 patients. Zhongguo Xiu Fu Chong Jian Wai Ke Za Zhi. 2009;23:14-20.

142. Chew S, Khandji AG, Montes J, Mitsumoto H, Gordon PH. Olfactory ensheathing glia injections in Beijing: misleading patients with ALS. Amyotroph Lateral Scler. 2007;8:314-316.

143. Blanquer M, Perez-Espejo MA, Martinez-Lage JF, Iniesta F, Martinez S, Moraleda JM. A surgical technique of spinal cord cell transplantation in amyotrophic lateral sclerosis. J Neurosci Methods. 2010. doi:10.1016/j.jneumeth.2010.06.014.

144. Feron F, Perry C, Cochrane J, et al. Autologous olfactory ensheathing cell transplantation in human spinal cord injury. Brain. 2005;128:2951-2960.
Stem Cells and Cloning: Advances and Applications

\section{Publish your work in this journal}

Stem Cells and Cloning: Advances and Applications is an international, peer-reviewed, open access journal. Areas of interest in stem cell research include: Embryonic cell stems; Adult stem cells; Blastocysts; Cordblood stem cells; Stem cell transformation and culture; Therapeutic cloning; Umbilical cord blood and bone marrow cells; Laboratory,

\section{Dovepress}

animal and human therapeutic studies; Philosophical and ethical issues related to stem cell research. This journal is indexed on CAS. The manuscript management system is completely online and includes a quick and fair peer-review system. Visit http://www.dovepress.com/ testimonials.php to read real quotes from published authors. 